\title{
RESPON IKAN SIDAT Anguilla bicolor bicolor TERHADAP MEDIA DENGAN SALINITAS BERBEDA
}

\section{THE RESPONSE OF ELL Anguilla bicolor bicolor AGAINST MEDIA WITH DIFFERENT SALINITIES}

\author{
Andre Rachmat Scabra ${ }^{* 1)}$, Tatag Budiardi ${ }^{2)}$ \\ ${ }^{1)}$ Program Studi Budidaya Perairan, Fakultas Pertanian, Universitas Mataram \\ ${ }^{2)}$ Program Studi Budidaya Perairan, Fakultas Perikanan dan Ilmu Kelautan, Institut Pertanian \\ Bogor
}

\begin{abstract}
Abstrak
Penelitian ini bertujuan untuk mengetahui pengaruh salinitas media yang berbeda terhadap kinerja produksi (derajat kelangsungan hidup, laju pertumbuhan mutlak biomassa, rasio konversi pakan, kadar glukosa darah, dan tingat konsumsi oksigen) ikan sidat Anguilla bicolor bicolor. Rancangan penelitian yang digunakan adalah RAL dengan empat pelakuan yang berbeda (A, $0 \mathrm{~g} / \mathrm{L} ; \mathrm{B}, 2 \mathrm{~g} / \mathrm{L} ; \mathrm{C}, 4 \mathrm{~g} / \mathrm{L}$; dan $\mathrm{D}, 6 \mathrm{~g} / \mathrm{L})$ dan tiga ulangan. Ikan sidat yang digunakan memiliki bobot rata-rata $8,4 \pm 0,32$ g/ekor dengan padat tebar $4 \mathrm{~g} / \mathrm{L}$. Hasil penelitian menunjukkan perlakuan A, yaitu pemeliharaan ikan sidat A. bicolor bicolor pada media bersalinitas $0 \mathrm{~g} / \mathrm{L}$ adalah perlakuan terbaik terhadap parameter uji (derajat kelangsungan hidup 100\%; laju pertumbuhan mutlak biomassa 9,31 g/hari; rasio konversi pakan 1,2; kadar glukosa darah 22,30 mg/dL; dan tingkat konsumsi oksigen 1,12 $\mathrm{mgO}_{2} / \mathrm{g} / \mathrm{jam}$ ). Kualitas air selama penelitian berada dalam kisaran optimal pemeliharaan ikan sidat (suhu 31,7-32,9 ${ }^{\circ} \mathrm{C}$; $\mathrm{pH} 7,6-7,7$; oksigen terlarut 5,4-5,8 mg/L; alkalinitas 31,2-39,5 $\mathrm{mg} / \mathrm{L}$; nitrit $0,26-0,52 \mathrm{mg} / \mathrm{L}$; dan amonia $0,001 \mathrm{mg} / \mathrm{L}$ ).
\end{abstract}

Kata kunci : Anguilla bicolor bicolor, ikan sidat, kinerja produksi, salinitas media

\begin{abstract}
This study aimed to determine effect of different salinity level of culture media for the production performance (survival rate, biomass growth rate, food conversion ratio, blood glucose content, and oxygen consumption rate) of eel Anguilla bicolor bicolor. The experimental designed completely randomize design (CRD) with four treatments which was different salinity level of culture media (A, $0 \mathrm{~g} / \mathrm{L} ; \mathrm{B}, 2 \mathrm{~g} / \mathrm{L} ; \mathrm{C}, 4 \mathrm{~g} / \mathrm{L}$; dan D, $6 \mathrm{~g} / \mathrm{L})$ and three replications. The eel with body weight average of $8,43 \pm 0.32 \mathrm{~g} / \mathrm{fish}$. The result of this study showed that treatment A was the best treatment (survival rate 100\%; biomass growth rate 9.31 $\mathrm{g} / \mathrm{day}$; and food conversion ratio 1.2 ; blood glucose content $22,30 \mathrm{mg} / \mathrm{dL}$; and oxygen consumption rate $\left.1.12 \mathrm{mgO}_{2} / \mathrm{g} / \mathrm{jam}\right)$. Water quality during the study are within the range of optimal maintenance of eels (temperature $31.7-32.9^{\circ} \mathrm{C}$; $\mathrm{pH} 7.6-7.7$; dissolved oxygen 5.4 $5.8 \mathrm{mg} / \mathrm{L}$; alkalinity $31,2-39,5 \mathrm{mg} / \mathrm{L}$; nitrite $0.26-0.52 \mathrm{mg} / \mathrm{L}$; and ammonia $0.001 \mathrm{mg} / \mathrm{L}$ ).

Keyword :_Anguilla bicolor bicolor, Indonesian eel, production performance, salinity media

\section{Pendahuluan}

Ikan sidat Anguilla bicolor bicolor merupakan komoditas perikanan yang

${ }^{*}$ korespondensi : andrescabra@unram.ac.id

memiliki nilai ekonomis dan permintaan yang tinggi baik di pasar lokal maupun internasional (Affandi 2005). Pasar lokal
\end{abstract}


ikan sidat untuk Daerah Khusus Ibu Kota Jakarta sebesar 36 ton/tahun dengan harga yang berkisar antara Rp 100.000-Rp $175.000 / \mathrm{kg}$ (KKP 2011). Kebutuhan pasar internasional ikan sidat mencapai jumlah 268.342 ton/tahun dengan harga yang berkisar antara Rp 180.000-Rp 225.000/kg (FAO 2014). Setianto (2015) menambahkan informasi bahwa Jepang merupakan negara konsumen ikan sidat terbesar dengan kisaran harga makanan olahan ikan sidat yang mencapai $\mathrm{Rp}$ 450.000/porsi makanan siap saji.

Tingginya harga ikan sidat tersebut salah satunya disebabkan karena kandungan gizinya yang tinggi. Nafsiyah et.al., (2018) menyatakan bahwa hasil proksimat tubuh ikan sidat menunjukkan bahwa lemak merupakan kadar nutrisi tertinggi yang ada pada tubuh ikan sidat. Kadar lemak yang terkandung tersebut adalah kadar lemak tak jenuh rantai ganda (polyunsaturated fatty acids) berupa omega 3 dan 6. Kedua bentuk asam lemak berfungsi dengan baik apabila komposisi dan konsentrasi ionik dalam tubuhnya tepat. Bentuk adaptasi ionik tersebut berkaitan erat dengan fungsi osmoregulasi, yaitu menciptakan komposisi dan konsentrasi ionik yang ideal antara intraseluler dengan ekstraseluler (Affandi dan Tang 2002).

Pada beberapa penelitian terdahulu, pemeliharaan ikan dengan berbagai tingkat salinitas yang berbeda memberikan pengaruh yang cukup signifikan terhadap nilai pertumbuhan. Scabra (2013) dan Kaligis et.al., (2009), menyatakan bahwa perbedaan nilai salinitas media dapat memberikan pengaruh terhadap pertumbuhan dan kehidupan udang vannamei Litopennaeus vannamei. Menurut Faturrohman (2012) pertumbuhan benih ikan patin Pangasius dapat dipengaruhi oleh nilai salinitas pada media pemeliharaannya. Abidin (2011) menyatakan bahwa penambahan kalsium pada media bersalinitas juga dapat memberikan pengaruh terhadap kehidupan dan pertumbuhan udang galah tak jenuh tersebut memiliki manfaat yang vital terhadap kesehatan.

Kebutuhan pasar ikan sidat masih cukup terbuka lebar. Hal tersebut diketahui karena permintaannya belum sepenuhnya tercukupi. Pada negara Jepang yang merupakan tujuan ekspor ikan sidat terbesar di dunia, dengan kebutuhan konsumsi sebesar 130.000 ton/tahun, baru terpenuhi sebesar $16,8 \%$, yaitu 21.000 ton (KKP 2011). Berdasarkan hal tersebut, maka teknologi budidaya ikan sidat untuk meningkatkan produksi masih sangat diperlukan dan dapat dilakukan dengan merekayasa kualitas air (faktor fisikakimia) sebagai media pemeliharaan.

Salah satu faktor lingkungan sebagai media pemeliharaan yang berpengaruh terhadap kehidupan ikan dan berhubungan erat dengan tekanan osmotik dan ionik air, adalah salinitas. Nilai salinitas pada lingkungan perairan yang optimal dapat mendukung pertumbuhan ikan dengan baik. Sel tubuh dapat Macrobrachium rosenbergii de Man. Berdasarkan hal tersebut, untuk mengoptimalkan pertumbuhan ikan sidat Anguilla bicolor bicolor, maka dapat dilakukan suatu kajian ilmiah mengenai pengaruh ikan sidat terhadap perbedaan salinitas pada media pemeliharaan.

\section{Metode \\ Waktu dan Tempat}

Penelitian ini dilakukan selama satu bulan. Pemeliharaan ikan dilakukan di Laboratorium Teknik Produksi dan Manajemen Akuakultur, sedangkan analisis kualitas air di lakukan di Laboratorium Lingkungan Akuakultur, Departemen Budidaya Perairan Institut Pertanian Bogor.

\section{Rancangan Percobaan}

Penelitian ini dilakukan dengan metode eksperimental. Rancangan percobaan yang digunakan adalah rancangan acak lengkap (RAL) dengan 4 perlakuan yaitu penambahan garam $(\mathrm{NaCl})$ dengan dosis berbeda untuk menghasilkan 
tingkat salinitas media yang berbeda pula; A $(0 \mathrm{~g} / \mathrm{L}), \mathrm{B}(2 \mathrm{~g} / \mathrm{L}), \mathrm{C}(4 \mathrm{~g} / \mathrm{L})$, dan D $(6$ $\mathrm{g} / \mathrm{L})$. Setiap perlakuan diulang sebanyak 3 kali.

\section{Prosedur Penelitian \\ Persiapan}

Wadah yang digunakan berupa 12 unit akuarium bersekat dengan sistem resirkulasi. Sekat berfungsi untuk memisahkan bagian filter dan bagian pemeliharaan. Dimensi akuarium berukuran $100 \times 50 \times 40 \mathrm{~cm}^{3}$, dengan bagian pemeliharaan berukuran $90 \times 50 \times 40 \mathrm{~cm}^{3}$ dan bagian filter berukuran $10 \times 50 \times 30$ $\mathrm{cm}^{3}$. Volume air yang digunakan adalah 90 L. Filter yang digunakan berupa satu unit filter yang berfungsi sebagai filter fisika, kimia, dan biologi. Pada setiap akuarium diberikan satu titik aerasi untuk meningkatkan kadar kosigen terlarut.

Bahan filter yang digunakan terdiri dari kapas sintetis, karbon aktif, zeolit, karang jahe dan bioball. Pada sistem resirkulasi, air dari akuarium pemeliharaan masuk ke dalam filter melalui pipa serapan dan dialirkan secara gravitasi. Air yang keluar langsung memasuki media filter secara berurutan, yaitu kapas, karbon aktif, karang jahe, zeolit, dan bioball. Air yang telah melewati filter akan mengalir ke dalam sekat penampungan air. Selanjutnya air tersebut dipompa ke dalam akuarium pemeliharaan melalui pipa inlet.

Sebelum digunakan, akuarium pemeliharaan dicuci, dibilas, dan dikeringkan. Akuarium yang telah siap kemudian diisi air sampai ketinggian 20 $\mathrm{cm}$ sehingga volume air media pemeliharaan 90 liter. Garam $(\mathrm{NaCl})$ ditambahkan dengan dosis berbeda untuk menghasilkan salinitas media yang sesuai dengan perlakuan masing masing.

\section{Pemeliharaan Ikan Uji}

Benih sidat yang digunakan memiliki bobot awal 10 \pm 1 g/ekor yang berasal dari muara Sungai Serayu, Kabupaten Cilacap, Jawa Tengah. Padat tebar ikan sidat pada setiap akuarium yaitu $4 \mathrm{~g} / \mathrm{L}$ atau 360 g/akuarium dan dipelihara selama 15 hari. Pakan yang diberikan berupa pakan komersial berkadar protein sebesar $45 \%$. Pakan tersebut diubah menjadi bentuk pasta dan diberikan secara at satiation dengan persentase pemberian antara 3-5\% dari biomassa. Frekuensi pemberian yaitu tiga kali sehari pada pagi (08.00), sore (15.00) dan malam (22.00). Untuk mempertahankan kualitas air, dalam media pemeliharaan dilakukan pergantian air setiap hari sejumlah $20 \%$ dari total volume air.

\section{Parameter Uji}

Derajat Kelangsungan Hidup (DKH)

DKH dihitung berdasarkan Goddard (1996):

$$
\mathrm{SR}=\frac{\mathrm{N}_{\mathrm{t}}}{\mathrm{N}_{0}} \times 100
$$

Keterangan:

$$
\begin{aligned}
\mathrm{SR}= & \text { Derajat kelangsungan hidup } \\
& (\%) \\
\mathrm{Nt} \quad & \begin{array}{l}
\text { Jumlah ikan pada waktu } \mathrm{t} \\
\text { (ekor) }
\end{array} \\
\mathrm{No} \quad= & \begin{array}{l}
\text { Jumlah ikan pada awal } \\
\text { percobaan (ekor) }
\end{array}
\end{aligned}
$$

\section{Laju Pertumbuhan Mutlak Biomassa (LPMB)}

LPMB dihitung berdasarkan

Goddard (1996):

$$
\mathrm{LPMB}=\frac{\mathrm{W}_{\mathrm{t}}-\mathrm{W}_{0}}{\mathrm{t}} \times 100
$$

Keterangan :

$$
\begin{aligned}
\mathrm{LPMB}= & \text { Laju pertumbuhan mutlak } \\
& \text { biomassa }(\mathrm{g} / \mathrm{hari}) \\
\mathrm{Wt} & =\begin{array}{l}
\text { Biomassa ikan sidat pada akhir } \\
\text { pemeliharaan }(\mathrm{g})
\end{array} \\
\mathrm{Wo}= & \begin{array}{l}
\text { Biomassa ikan sidat pada awal } \\
\text { pemeliharaan }(\mathrm{g})
\end{array} \\
\mathrm{t} & =\text { Periode pemeliharan (hari) }
\end{aligned}
$$

\section{Glukosa Darah (GD)}

GD dihitung dengan metode enzimatik menggunakan tool kit bood glucose test meter (Gluco Dr. Auto AGM4000). 


\section{Tingkat Konsumsi Oksigen (TKO)}

TKO dihitung berdasarkan rumus Liao dan Huang (1975).

$$
\mathrm{TKO}=\frac{\mathrm{V}(\mathrm{OTto}-\mathrm{OTt})}{\mathrm{w} \times \mathrm{t}}
$$

Keterangan :

$$
\begin{aligned}
& \text { TKO = } \text { Tingkat konsumsi oksigen } \\
&(\mathrm{mgO} 2 / \mathrm{g} / \mathrm{jam}) \\
& \mathrm{V}= \text { Volume air dalam wadah }(\mathrm{L}) \\
& \mathrm{OTto}= \text { Konsentrasi oksigen terlarut } \\
& \text { pada awal pengamatan }(\mathrm{mg} / \mathrm{L})
\end{aligned}
$$

$$
\begin{aligned}
\mathrm{OTtt}= & \text { Konsentrasi oksigen terlarut } \\
& \text { pada waktu } \mathrm{t}(\mathrm{mg} / \mathrm{L}) \\
\mathrm{w} & = \\
\mathrm{t} & \text { Bobot ikan uji }(\mathrm{g}) \\
= & \text { Periode pengamatan }(\mathrm{jam})
\end{aligned}
$$

\section{Parameter Kualitas air}

Parameter kualitas air yang diukur antara lain salinitas, suhu, oksigen terlarut (OT), $\mathrm{pH}$, nitrit $\left(\mathrm{NO}_{2}^{-}\right)$, amonia $\left(\mathrm{NH}_{3}\right)$, alkalinitas, (Tabel 1).

Tabel 1. Parameter kualitas air pemeliharaan ikan sidat Anguilla bicolor bicolor pada tingkat salinitas media berbeda; A (0 g/L), B (2 g/L), C (4 g/L), dan D (6 g/L)

\begin{tabular}{lll}
\hline Parameter & Satuan & Alat ukur/Metode \\
\hline Salinitas & $\mathrm{g} / \mathrm{L}$ & Salinometer \\
Suhu & ${ }^{\circ} \mathrm{C}$ & Termometer \\
Oksigen terlarut & $\mathrm{mg} / \mathrm{L}$ & DO-meter \\
$\mathrm{pH}$ & - & $\mathrm{pH}-$ meter \\
$\mathrm{Nitrit}\left(\mathrm{NO}_{2}^{-}\right)$ & $\mathrm{mg} / \mathrm{L}$ & Spektrofotometer \\
Amonia $\left(\mathrm{NH}_{3}\right)$ & $\mathrm{mg} / \mathrm{L}$ & Spektrofotometer \\
Alkalinitas Total & $\mathrm{mg} / \mathrm{L}$ & Titrimetrik \\
\hline
\end{tabular}

\section{Analisis Data}

Data yang diperoleh ditabulasi dengan Microsoft Excel 2007. Parameter derajat kelangsungan hidup dan laju pertumbuhan mutlak biomassa dianalisis ragam (ANOVA) pada selang kepercayaan 95\% dengan bantuan perangkat lunak SPSS 17.0. Apabila data berbeda nyata maka dilanjutkan dengan uji Duncan. Parameter glukosa darah (GD), tingkat konsumsi oksigen (TKO), dan kualitas air dianalisis secara deskriptif yang disajikan dalam bentuk tabel dan grafik.

\section{Hasil}

Parameter yang diamati meliputi derajat kelangsungan hidup (DKH), laju pertumbuhan mutlak biomassa (LPMB), kadar glukosa darah (GD), dan tingkat konsumsi oksigen (TKO) yang disajikan pada Tabel 2.

Tabel 2 Hasil penelitian pemeliharaan ikan sidat Anguilla bicolor bicolor pada tingkat salinitas media berbeda; A (0 g/L), B (2 g/L), C (4 g/L), dan D (6 g/L)

\begin{tabular}{lcccc}
\hline \multicolumn{1}{c}{ Parameter } & \multicolumn{4}{c}{ Perlakuan Salinitas media (g/L) } \\
\hline $\begin{array}{l}\text { Derajat kelangsungan hidup (\%) } \\
\text { Laju pertumbuhan mutlak biomassa } \\
\text { (g/hari) }\end{array}$ & $100 \pm 0^{\mathrm{a}}$ & $100 \pm 0^{\mathrm{a}}$ & $100 \pm 0^{\mathrm{a}}$ & $100 \pm 0^{\mathrm{a}}$ \\
Kadar glukosa darah (mg/dL) & $9,31 \pm 0,26^{\mathrm{a}}$ & $6,09 \pm 0,74^{\mathrm{b}}$ & $4,44 \pm 2,20^{\mathrm{b}}$ & $4,51 \pm 0,94^{\mathrm{b}}$ \\
$\begin{array}{l}\text { Tingkat konsumsi oksigen } \\
\text { (mgO2/g/jam) }\end{array}$ & $22,30 \pm 8,91$ & $30,03 \pm 5,50$ & $45,88 \pm 2,88$ & $61,70 \pm 8,91$ \\
& $1,12 \pm 0,27$ & $1,28 \pm 0,13$ & $1,27 \pm 0,15$ & $1,42 \pm 0,70$ \\
\hline
\end{tabular}


Angka-angka pada baris yang sama yang diikuti oleh huruf superscript yang sama tidak berbeda nyata pada taraf uji 5\% (uji selang berganda Duncan).

Hasil uji analisis ragam (ANOVA) menunjukkan bahwa perlakuan tidak memberikan pengaruh nyata terhadap nilai derajat kelangsungan hidup, namun memberikan pengaruh nyata terhadap nilai laju pertumbuhan mutlak biomassa $(\mathrm{P}>0,05)$, di mana perlakuan A memberikan nilai tertinggi yaitu 9,31 $\mathrm{g} /$ hari dan perlakuan D memberikan nilai terendah yaitu 4,51 g/hari.. Parameter kadar glukosa darah dan tingkat konsumsi oksigen dianalisis secara deskripitif, yaitu semakin rendah kadar glukosa darah serta tingkat konsumsi oksigen pada batas normal, maka akan semakin baik bagi ikan. Kadar glukosa darah terendah terjadi pada perlakuan A yaitu 22,30 $\mathrm{mg} / \mathrm{dL}$, dan tertinggi pada perlakuan D yaitu 61,70 $\mathrm{mg} / \mathrm{dL}$. Tingkat konsumsi oksigen terendah terjadi pada perlakuan A yaitu 1,12 $\mathrm{mgO} 2 / \mathrm{g} / \mathrm{jam}$, dan tertinggi pada perlakuan D yaitu $1,42 \mathrm{mgO} 2 / \mathrm{g} / \mathrm{jam}$.

Parameter kualitas air yang diukur meliputi salinitas, suhu, $\mathrm{pH}$, oksigen terlarut (OT), alkalinitas, nitrit $\left(\mathrm{NO}_{2}{ }^{-}\right)$, dan amonia $\left(\mathrm{NH}_{3}\right)$ yang disajikan Tabel 3.

Tabel 3. Hasil uji kualitas air pemeliharaan ikan sidat Anguilla bicolor bicolor pada tingkat salinitas media berbeda; A $(0 \mathrm{~g} / \mathrm{L}), \mathrm{B}(2 \mathrm{~g} / \mathrm{L}), \mathrm{C}(4 \mathrm{~g} / \mathrm{L})$, dan D $(6 \mathrm{~g} / \mathrm{L})$

\begin{tabular}{|c|c|c|c|c|c|}
\hline \multirow{2}{*}{ Kualitas Air } & \multicolumn{4}{|c|}{ Perlakuan salinitas media (g/L) } & \multirow{2}{*}{$\begin{array}{c}\text { Kisaran } \\
\text { Optimum }\end{array}$} \\
\hline & $\mathrm{A}(0)$ & $\mathrm{B}(2)$ & $\mathrm{C}(4)$ & $\mathrm{D}(6)$ & \\
\hline $\begin{array}{l}\text { Salinitas } \\
(\mathrm{g} / \mathrm{L})\end{array}$ & 0 & 2 & 4 & 6 & - \\
\hline Suhu $\left({ }^{\circ} \mathrm{C}\right)$ & $31,7 \pm 0,7$ & $32,8 \pm 0,8$ & $32,1 \pm 1,3$ & $32,9 \pm 0,6$ & $\begin{array}{l}\text { 23-31 (Usui } \\
1974)\end{array}$ \\
\hline $\mathrm{pH}$ & $7,7 \pm 0,1$ & $7,6 \pm 0,1$ & $7,7 \pm 0,1$ & $7,6 \pm 0,2$ & $\begin{array}{l}6,0-8,0 \\
\text { (Ritonga } \\
2014 \text { ) }\end{array}$ \\
\hline OT (mg/L) & $5,8 \pm 0,8$ & $5,5 \pm 0,5$ & $5,5 \pm 0,7$ & $5,4 \pm 0,6$ & $\begin{array}{l}>3,0 \\
\text { (Heriyanti } \\
2005 \text { ) }\end{array}$ \\
\hline $\begin{array}{l}\text { Alkalinitas } \\
(\mathrm{mg} / \mathrm{L})\end{array}$ & $39,5 \pm 9,0$ & $31,2 \pm 6,2$ & $36,4 \pm 4,8$ & $34,3 \pm 3,1$ & $\begin{array}{l}30-500 \\
\text { (Boyd 1990) } \\
<0,5\end{array}$ \\
\hline Nitrit $(\mathrm{mg} / \mathrm{L})$ & $0,26 \pm 0,10$ & $0,38 \pm 0,00$ & $0,52 \pm 0,10$ & $0,47 \pm 0,10$ & $\begin{array}{l}\text { (Knosche } \\
\text { 1994) }\end{array}$ \\
\hline $\begin{array}{l}\text { Amonia } \\
(\mathrm{mg} / \mathrm{L})\end{array}$ & $0,001 \pm 0,000$ & $0,001 \pm 0,000$ & $0,001 \pm 0,010$ & $0,001 \pm 0,000$ & $\begin{array}{l}<0,1 \\
\text { (Yamagata } \\
\text { \& Niwa } \\
1982 \text { ) }\end{array}$ \\
\hline
\end{tabular}

\section{Hasil}

Derajat kelangsungan hidup (DKH) ikan sidat menghasilkan nilai yang seragam pada setiap perlakuan dan ulangan yaitu $100 \%$. Tingginya nilai DKH tersebut mengindikasikan bahwa ikan sidat mampu beradaptasi dengan baik terhadap perlakuan salinitas yang diterapkan. Menurut Usui (1974) ikan sidat merupakan organisme euryhaline, yaitu organisme yang mampu bertahan hidup pada berbagai tingkat salinitas media. Hal tersebut terlihat dari siklus hidupnya di mana ikan 
sidat dewasa akan beruaya menuju laut dalam untuk bereproduksi, kemudian benih pada fase glass eel akan melakukan ruaya kembali menuju kawasan perairan tawar untuk hidup dan berkembang. Scabra (2019), menambahkan bahwa apabila ikan hidup pada suatu media dengan nilai kisaran yang sesuai dengan kebutuhannya, maka ikan tersebut setidak-tidaknya dapat bertahan hidup dengan baik.

Laju pertumbuhan mutlak biomassa (LPMB) ikan sidat tertinggi terjadi pada perlakuan A. Hal tersebut diduga disebabkan oleh sifat hidup ikan sidat yaitu pada tahap pembesaran lebih menyukai lingkungan dengan salinitas yang rendah. Seperti yang dikemukakan oleh Usui (1974) bahwa ikan sidat pada fase pertumbuhan akan beralih dari lingkungan perairan laut menuju ke perairan tawar. Pada perairan tawar, ikan sidat diduga lebih merasa nyaman sehingga pembelanjaan energi metabolisme untuk mencapai homeostasi tubuh menjadi minim yang kemudian menyebabkan budget untuk pertumbuhan menjadi lebih besar.

Hasil pengamataan kadar glukosa darah ikan sidat menunjukkan pola yang cenderung sama dengan nila laju pertumbuhan mutlak biomassa, yaitu perlakuan A menghasilkan nilai yang terendah. Hal tersebut mengindikasikan bahwa ikan sidat pada perlakuan A mengalami kondisi stres yang paling rendah dibandingkan dengan perlakuan lain. Affandi dan Tang (2002) menyatakan bahwa pada kondisi stres, ikan akan mengalami penurunan volume darah, penurunan jumlah leukosit, penurunan glikogen hati dan peningkatan kadar glukosa darah. Kondisi stres tersebut dapat terjadi karena adanya perubahan lingkungan akibat perubahan salinitas. Dalam kondisi stres, ikan akan mengembangkan suatu kondisi homeostasi yang baru dengan meningkatkan aktivitas metabolismenya. Peningkatan aktivitas metabolisme tersebut kemudian menyebabkan terjadinya peningkatan laju konsumsi oksigen.

Gracia et al. (2006) menyatakan bahwa tingkat konsumsi oksigen (TKO) dapat digunakan sebagai parameter untuk mengetahui laju metabolisme organisme air. Semakin rendah nilai TKO maka semakin sedikit energi yang digunakan untuk metabolisme sehingga semakin banyak energi yang tersedia untuk pertumbuhan. Berdasarkan Tabel 3, diketahui bahwa nilai TKO pada perlakuan A adalah yang terendah dibandingkan dengan perlakuan B, C, dan D. Terkait dengan budged energi untuk metabolisme dan pertumbuhan, rendahnya TKO pada perlakuan A memiliki pola yang cenderung sama dengan tingginya nilai LPMB. Pada penelitian serupa yang dilakukan oleh Scabra (2016), kadar nilai TKO ikan yang dipelihara pada media yang berbeda menunjukkan nilai yang berbeda pula. Hal tersebut menguatkan dugaan bahwa kadar nilai TKO berpengaruh terhadap aktifitas metabolisme yang disebabkan perbedaan media pemeliharaan.

Kualitas air pemeliharaan yang baik dapat mendukung pertumbuhan dan kelangsungan hidup ikan sidat secara optimal. Berdasarkan Tabel 3, kualitas air selama penelitian berada pada kisaran yang sesuai dengan kriteria pemeliharaan ikan sidat. Kualitas air yang baik tersebut disebabkan oleh metode pengelolaan kualitas air yang tepat, yaitu dengan sistem resirkulasi dan pergantian air setiap hari sejumlah $20 \%$ dari total volume air pemeliharaan.

Sistem resirkulasi merupakan sebuah sistem yang mengalirkan air yang kotor pada wadah pemeliharaan menuju wadah filtrasi untuk disaring. Air yang telah tersaring tersebut kemudian dialirkan kembali menuju wadah pemeliharaan ikan. Sistem filtrasi air tersebut melibatkan beberapa komponen seperti filter fisik berupa kapas sintetis, filter kimia berupa zeolit dan karbon aktif, serta filter biologis berupa bioball. Kapas sintetis berperan dalam menyaring padatan tersuspensi 
dalam air berupa sisa pakan yang tidak termakan dan feses dari ikan. Zeolit dan karbon aktif berperan dalam penyerapan zat beracun seperti amonia dan nitrit (Supriyono et al., 2007). Bioball berperan sebagai media tempat pelekatan mikroba (bakteri nitrifikasi) yang berperan dalam mendegradasi nitrogen ke dalam bentuk nitrat yang tidak beracun bagi ikan (Dewi \& Masithoh, 2013). Hal tersebut dikuatkan oleh hasil penelitian Nurhidayat et al. (2012) bahwa kombinasi sistem resirkulasi antara zeolit, karbon aktif dan bioball dapat menghasilkan kualitas air yang baik melalui oksidasi amonia dan penumbuhan koloni bakteri nitrifikasi nonpatogen.

\section{Kesimpulan}

Perlakuan terbaik pada penelitian ini adalah perlakuan A, yaitu pemeliharaan ikan sidat $A$. bicolor bicolor pada media bersalinitas $0 \mathrm{~g} / \mathrm{L}$ berdasarkan parameter uji derajat kelangsungan hidup 100\%; laju pertumbuhan mutlak biomassa 9,31 g/hari; rasio konversi pakan 1,2; kadar glukosa darah 22,30 mg/dL; dan tingkat konsumsi oksigen $1,12 \mathrm{mgO}_{2} / \mathrm{g} / \mathrm{jam}$.

\section{Daftar Pustaka}

Abidin, J. (2011). Penambahan kalsium untuk meningkatkan kelangsungan hidup dan pertumbuhan juvenil udang galah Macrobrachium rosenbergii de Man pada media bersalinitas [tesis]. Bogor (ID): Institut Pertanian Bogor.

Affandi, R. \& Tang, M. (2002). Fisiologi Hewan Air. Jakarta (ID): Unri Press.

Affandi, R. (2005). Strategi pemanfaatan sumberdaya ikan sidat Anguilla sp. di Indonesia. Jurnal lktiologi Indonesia. 5 (2), 77 - 81.

Boyd, C.E. (1990). Water Quality in Pond for Aquaculture. Alabama (US): Auburn University.

Dewi \& Masithoh, 2013
Faturrohman, K. (2012). Pemberian kalsium karbonat (CaCO3) pada media bersalinitas untuk pertumbuhan benih ikan patin Pangasius sp. [skripsi]. Bogor (ID): Institut Pertanian Bogor.

[FAO] Food and Agriculture Organization. (2014). Globefish research programme, eel Anguilla spp.: production and trade. Rome (IT): FAO Fishstat Plus.

Gracia, L.A., Rosas, V.C. \& Brito, P.R. (2006). Effects of salinity on physiological conditions in juvenile common snook Centropomus undecimalis. Elsevier Comparative Biochemistry and Physiology. 145, 340-345.

Herianti, I. (2005). Rekayasa lingkungan untuk memacu perkembangan ovarium ikan sidat Anguilla bicolor bicolor. Oseanologi dan Limnologi Indonesia. 37, 25-41.

Kaligis, E., Djokosetiyanlo, D. \& Affandi, R. (2009). Pengaruh penambahan kalsium dan salinitas aklimasi Terhadap peningkatan sintasan postlarva udang vannamei Litopenaeus vannamei Boone. Jurnal Kelautan Nasional. 2, 101108.

[KKP] Kementerian Kelautan dan Perikanan. (2011). Panduan budidaya ikan sidat Anguilla spp. Jakarta (ID): KKP RI.

Knosche, R. (1994). An effective biofilter type for eel culture in resirculation system. Elsevier Aquaculture Engineering. 13, 71-82.

Nafsiyah, I., Nurilmala, M. \& Abdullah, A. (2018). Komposisi nutrisi ikan sidat Anguilla bicolor bicolor dan Anguilla marmorata. Jurnal Pengolahan Hasil Perikanan Indonesia. 21(3), 504-512. 
Nurhidayat, Nirmala, K. \& Djokosetyanto, D. (2012). Efektivitas kinerja media biofilter dalam sistem resirkulasi terhadap kualitas air untuk pertumbuhan dan sintasan ikan red rainbow Glossolepis incisus Weber. Jurnal Riset Akuakultur. 7, 89-96.

Ritonga, T. (2014). Respons benih ikan sidat Anguilla bicolor bicolor terhadap derajat keasaman $(\mathrm{pH})$. [skripsi]. Bogor (ID): Institut Pertanian Bogor.

Scabra, A.R. (2013). Pemberian Jenis Pakan Yang Berbeda pada Pemeliharaan Udang Vannamei Litopenaeus vannamei dengan Media Bersalinitas Rendah. [skripsi]. Malang (ID): Universitas Muhammadiyah Malang.

Scabra, A.R., Budiardi, T. \& Setyanto, D.D. (2016). Kinerja produksi ikan sidat Anguilla bicolor bicolor berukuran 10 gram dengan pemberian kalsium karbonat $\left(\mathrm{CaCO}_{3}\right)$ pada media budidaya Jurnal Akuakultur Indonesia, 15 (1), $1-7$.

Scabra, A.R. \& Setyowati, D.N. (2019). Peningkatan mutu kualitas air untuk pembudidaya ikan air tawar di Desa Gegerung Kabupaten Lombok Barat. Abdi Insani. 6 (2), 267-275.

Supriyono, E., Supendi, A. \& Nirmala, K. (2007). Pemanfaatan zeolit dan karbon aktif pada sistem pengepakan ikan corydoras Corydoras aenus. Jurnal Akuakultur Indonesia, 6, 135 -145 .

Usui, A. (1974). Eel Culture. London (UK): Fishing news.

Yamagata, Y. \& Niwa, M. (1982). Acute and chronic toxicity of ammonia to eel Anguilla japonica. Bulletin of the Japanese Society for the Science of Fisheries, 48 (2), 171176. 